\title{
CAIXA POSTAL 15OO : ANO 446 DA ERA DA DEGLUTIÇÃO DO BISPO SARDINHA, PELO OFICINÃO GALPÃO
}

\author{
Júnia de Castro Magalhães Alves \\ Universidade Federal de Minas Gerais \\ Unicentro Newton Paiva \\ Lúcia Trindade Valente \\ Universidade Federal do Rio Grande do Sul \\ O cronista que narra os acontecimentos, sem distinguir \\ entre os grandes e os pequenos, leva em conta a \\ verdade de que nada do que um dia acontece pode \\ ser considerado perdido para a história. \\ Walter Benjamim em Sobre o conceito da bistória
}

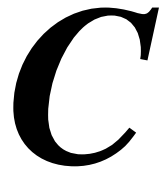

aixa Postal 1500, comédia histórica em um ato, dirigida e produzida pelo $2^{\circ}$ Oficinão Galpão Cine Horto (Oficina de Atores e de Dramaturgia do Grupo Galpão - 1999), foi escrita e encenada para celebrar os quinhentos anos a partir da data da chegada de Pedro Alvares Cabral às costas do Brasil. A montagem, uma incursão no universo do descobrimento, retrata um olhar coletivo sobre o caráter, a formação e a colonização do País. Assina o texto uma equipe composta por Georgia Oliveira, Ítalo Mudado, Ivana Andrés Ribeiro, Jória Batista de Sousa, Marcelo Braga de Freitas, Marcelo Henrique Costa, Maria Cristina de Andrade, Miguel Anunciação, Sérgio Luiz e Sofia Martins. A direção é de Júlio Maciel. A peça, que congrega 19 atores (entre 19 e 46 anos) e, aproximadamente, 50 pessoas envolvidas na produção, teve apoio das leis municipal, estadual e federal de incentivo à cultura, e patrocínio majoritário da Telemig Celular. Foi representada pela primeira vez na sede do Grupo Galpão, na rua Pitangui 3.413, bairro da Sagrada Família, em Belo Horizonte, em pré-estréia para convidados nos dias 25 e 26 de janeiro de 2000 e, no dia 27, para o público mineiro. 
Para fundamentar o trabalho, o grupo, além de dispor de assessoria acadêmica de pesquisa histórica oferecida por professores da UFMG (Universidade Federal de Minas Gerais), estabeleceu contato com os pataxós - cujos remanescentes vivem nas terras do posto indígena Paraguaçu, no município de Itabuna na Bahia - e participou do $2^{\circ}$. Festival de Cultura Indígena da Serra do Cipó, onde se reuniram sete tribos. A produção é um encontro de história, música, teatro e literatura, no qual o "Manifesto antropófago", 1 de Oswald de Andrade, ocupa lugar de destaque por sua natureza crítica condizente com o tom, isto é, com a atmosfera psicológica do espetáculo.

O uso antropofágico é uma forma de destronização. Ele penetra no universo do poder e do sublime para desconstruí-lo pela sátira, pela ironia, e mais intensamente pela paródia demolidora. O discurso antropofágico é dialógico e apreende o mundo como uma posição interpretativa, sempre focalizando não mais uma única verdade cartesiana, mas sim uma multiplicidade de contradições; assemelha-se a um baile de máscaras onde os participantes se confundem, se afirmam e se desmentem.

A forma escolhida para a construção da peça é a de um diálogo entre o passado e o presente, no qual se acomodam fatos históricos, músicas, canções e textos literários, que transportam a platéia para o contexto do Brasil colonial do século XVI e que transitam em um movimento cronotópico de ida e volta no tempo e no espaço.

Para a visualização dessa idéia o palco divide-se em dois níveis, sendo que o inferior apresenta uma clareira na floresta e o superior descortina o horizonte, o mar, um veleiro estilizado e, mais concreta-mente, uma pilha de sacos de carregamento ou lastro de navio. Unem-se dessa forma o Novo e o Velho Mundo, num contar da história que, como define Walter Benjamim, "é objeto de uma continuação cujo lugar não é o tempo homogêneo e vazio, mas um tempo saturado de 'agoras'."

\footnotetext{
${ }^{1}$ ANDRADE, como citado em TELES, 1992. p.353.

${ }^{2}$ BENJAMIN, 1994. p.229.
} 
Ao recontar o conto brasileiro na sua nova forma, mais voltada para o visual do que para a palavra, Caixa Postal 1500 assinala, para o espectador ouvinte, questões relevantes da prática política desta Nação, que, à semelhança de outras, constitui-se como o resultado de agentes históricos, a saber: o índio, o negro, o português, o jesuíta, os navegadores, os aventureiros, o rei, o poeta, o político, o folião, o francês, o holandês, a literatura, o teatro, a espada, a flecha, a selva, a clareira, o mar, o navio, os nós, o sol e a sombra, o lastro e a carga, entre tantos outros mencionáveis. Se não se aceitam todos os fatores constituintes do organismo nacional, destroi-se a nacionalidade pelo estabelecimento de distinções desnecessárias, pelo desmembramento nuclear do todo, pela idéia que dela formamos e que não é, naturalmente, o concreto materializado. Para que a aceitação se realize, não se pode conceder prioridade a nenhum dos fatores históricos, pois a reprodução da história não se faz sem o senso da totalidade, "o que na verdade, foi o que nós próprios nos propusemos a fazer, tentando sintetizar a nossa história em uma hora e meia de espetáculo.", explica Júlio Maciel. ${ }^{3}$ O Brasil é, e tem sido, um país de imigrações, um cadinho de etnias e, provavelmente, continuará a sê-lo por motivos geográficos e econômicos demasiadamente conhecidos.

Para pôr em cena a história nacional, uma personagem tensa e apressada (representada por Bete Penido), que funciona metateatralmente como narradora e diretora da peça em questão, entra no palco. Ela veste e desveste, por várias vezes, um colete de tecido artesanal, do qual direito e avesso se assemelham e que, embora diferentes, constituem um todo, como também o constituem os dois lados de uma mesma moeda, ou os pontos de vista das testemunhas de um mesmo fato. Dirigindo-se em aparte, à platéia, confessa sua perplexidade de cidadã ao discorrer e ponderar sobre os 500 anos de descobrimento(s) e, paradoxalmente, de encobrimento(s) de terras e da história do Brasil e de além mar. Em seu monólogo, a narradora compara

${ }^{3}$ CASSESE, 27 jan. 2000, p.3. (Entrevista com Júlio Maciel.) 
os indivíduos comuns a fios e nós que se unem para tecer os caminhos da humanidade e que, muitas vezes, são desatados por "Grandes ou minúsculos Alexandres" a golpes de espada. ${ }^{4}$ Em relação a essa passagem, dentre outras, o diretor dos trabalhos, Júlio Maciel, revela, em entrevista ao jornalista Pablo Pires, que "o espetáculo conta um pouco da própria experiência de construir a peça”, definida por Maciel como um épico que contém várias linguagens, incluindo o humor, o nonsense o drama, e que é apresentado por meio de fragmentos obturados pela personagem diretora. ${ }^{5}$

Nessa história-História a ação, ora contada, ora interpretada pelos atores, configura-se e se insere em superposições dramáticas que brincam com o enigma do jogo cênico. Ao percorrer tantas imagens-clichês coesas e/ou contraditórias, tais como a hospitalidade e a antropofagia dos índios caiowás-guaranis; a ganância e o sonho dos aventureiros portugueses; a força de trabalho e o conformismo ironizado dos escravos africanos; e o papel conflitante das mulheres - esposas, amantes ou prostitutas - independentemente da raça, ou classe sócio-econômica em que se enquadram, o texto consegue criar uma unidade. A fábula transfigura-se em múltiplos episódios tecidos e costurados na fala de quem, narrando, dirige os trabalhos, ao passo que monta as imagens em que se desenvolve o espetáculo. As formas dramáticas interpõem-se para forjar a própria história, igualmente inserida no conteúdo da fala.

Tomando como foco temático o nascer, o crescer e o ser brasileiro, esta produção desperta no espectador uma curiosidade, ou interesse, ou fascínio pela cultura, ou, mais precisamente, pelas culturas formadoras da unidade nacional, incitando nele uma resposta que certamente apresentará nuanças de ingenuidade, sentimentalismo e análise crítica.

Os diversos episódios do macrossigno Caixa Postal 1500 calcam-se em situações fictícias denominadas petits récits pelo

${ }^{4}$ OLIVEIRA, 2000. p.1.

${ }^{5}$ PIRES, 2000. p.8. (Entrevista com Júlio Maciel.) 
teórico francês Jean-François Lyotard e distintas do grand récit, que compreende uma história totalizante, íntegra, progressiva e contínua - a história que parece saber onde começou e para onde vai. As cenas do texto em questão são descontínuas e fragmentadas. Como uma colcha de retalhos, o todo é representado numa sucessão de situações não cronológicas que, entretanto, não compromete a compreensão em meio dos achados sígnicos, desdobrando-se com ritmo e cadência. A multiplicidade das vozes é resultado de um simultâneo entrecruzar de consciências, ou falas, independentes e distintas de universos que não se confundem. A polifonia define-se, assim, como uma reunião de materiais heterogêneos, uma pluralidade de centros não redutíveis a um denominador ideológico comum.

A força deste trabalho histórico jaz, não na expansão gradual e sistemática da cristandade e da civilização no mundo novo, mas no choque do não familiar, na provocação da curiosidade voltada para a saga dos índios caiowás-guaranis, na descontinuidade do tom e do ponto de vista das várias personagens da peça. Dessa forma, a colonização brasileira apresenta-se em encontros sucessivos e experiências ocasionais, de modo não antecipado, e mais associados à periferia em rotação, do que ao centro estático. Os quadros, ou episódios, são produtos da tecnologia representativa de uma cultura, retirados do palco da vida, moldados de forma provisional e contingente, e recortados como ficção.

Essas histórias, estudadas e registradas em documentos e em livros científicos ou didáticos, unem-se às imaginadas para produzir um efeito do localmente real. Isso denota que suas representações são não somente produtos, como também produções de significados capazes de alterar as mesmas forças que as criaram. Na verdade, a ênfase dada ao poder produtivo da representação sublinha a diferença entre a prática mimética e a prática social, isto é, entre a cópia artística e a "realidade" brasileira, embora uma não se isole totalmente da outra, mesmo que os autores do texto rejeitem propositadamente a reprodução impossível do fato, por meio de manipulações estratégicas, distorções e/ou supressões conscientes. 
A proposta de Caixa Postal 1500 não é distinguir as representações fictícias ("falsas") das verdadeiras ("fatuais"), mas ponderar sobre a natureza das práticas representativas reveladas pela narrativa histórica. Assim sendo, essa comédia mostra ceticismo e ironia em relação à acuidade e confiabilidade do discurso tradicional a respeito da terra e do povo brasileiro. Paradoxalmente, a solidez e a força do sentido histórico do evento devem-se a uma pesquisa atenta e à assessoria dos professores de História e Ciência Política: Carla Maria Junho Anastasia, Ciro Flávio Castro Bandeira de Melo, José Monroe Eisenberg e Maria Efigênia Lage de Resende, da Universidade Federal de Minas Gerais. Portanto o texto, ironicamente, não foge à mediação e à informação das próprias narrativas questionadas, não deixa de ser mais um ponto de vista da realidade, e é cabível, como qualquer outro, de suspeita epistemológica.

Uma conclusão possível, simples e clara, é a de que as produções históricas falam-nos, tanto dos objetos representados , quanto da ideologia e da prática representativa de seus autores.

Nessa esteira, as imagens de traição e de desespero irremediável, sinalizadas na peça pelo extermínio das tribos indígenas, pela escravidão do negro e pelo uso da mulher como objeto sexual criam uma espécie de pathos doméstico e nacional, enfatizado pela técnica da narrativa aparentemente descompromissada, mas tensa, visando a problematizar, com ironia e sátira, sentimentalismo e dramaticidade, as diferentes realidades brasileiras, sejam elas representadas pela comunidade negra, pela indígena, ou pela portuguesa.

É assim que Caixa Postal 1500 examina os fracassos e o determinismo a que se sujeitam vidas desesperadas no decorrer do processo da colonização. Apresenta cenas de alienação, aridez cultural, fanatismo, crueldade, demência, embriaguez, circunstâncias que funcionam como substitutas das frustrações individuais. É um teatro que tem como foco temático uma seqüência de desentendimentos e de discordância. Oferece uma psicopatologia dos grupos formadores da civilização e cultura brasileira, ao mesmo tempo que questiona a natureza das sociedades e, mais que isso, a metafísica da responsabilidade moral. 
A performance do texto descortina uma polifonia e intersemiose de linguagens, da qual participam Pero Vaz de Caminha, Manuel Bandeira, Thornton Wilder, Pelé, o bispo Sardinha, Oswald de Andrade - personalidades diversas e bem conhecidas - em assonância com a história, a teoria literária, a poesia, a técnica narrativa, as músicas de carnaval, o futebol, a favela, a senzala, o açúcar, o café e outras considerações.

De Caminha, em intertexto com o padre Anchieta, que escreveu poemas na areia, acha-se uma alusão às cartas, no diálogo entre os jesuítas Gusmão, Navarro e Mariano:

GUSMÃO: ...E estoutro palerma, o que está a fazer?

MARIANO: Estou a escrever o rascunho de uma carta que enviarei a nosso estimado Rei, descrevendo as maravilhas dessa terra.

GUSMÃO: (irônico) Rascunho de uma carta, pois veja só. Estamos nós cá a tentar encontrar o caminho e tu estás a rabiscar besteiras no chão.

MARIANO: (para de escrever, irritado) Não são besteiras!

NAVARRO: (aproxima-se dos escritos no solo e começa a lê-los) (...) "e em tal maneira é graciosa que, querendo-a aproveitar, dar-se-á nela tudo, por causa das águas que tem. ${ }^{6}$

O texto adota frases do escrivão português que ressaltam as belezas naturais do Brasil. É válida a conscientização de que na peça, Mariano, personagem fictícia, aglutina duas personalidades, a de uma mulher disfarçada em jesuíta e a do padre Anchieta, este ocupante de lugar de destaque nos livros tradicionais que contam a história do Brasil. Foi missionário; catequista e pedagogo; pioneiro na tentativa de compreender a cultura indígena; autor da primeira gramática em tupiguarani, então chamada língua geral do país, e de importantes autos sacramentais em tupi e em português. Em meio a sua obra completa destacam-se os Manuais de catequese, equivalentes aos livros de catecismo atuais. Anchieta é considerado também um grande

${ }^{6}$ OLIVEIRA, 2000. p.10. 
humanista. Escreveu poemas em latim: "De beata virgine", em louvor a Maria e "De gentis Mendi Sa", sobre a conquista do Rio de Janeiro, aos franceses, pelos portugueses. Seus dotes de exímio mestre-escola e pregador aliavam-se à capacidade de falar a todos, índios ou não. Preocupado com a cultura e a situação do povo indígena, criou o sistema de aldeamento, uma forma de defender as tribos e seus homens da cobiça dos colonizadores que queriam escravizá-los. É expressivo que Caixa Postal 1500 tenha-lhe atribuído alma e corpo femininos. A catequese dos gentios pelos religiosos é tratada, na peça, em tom satírico.

Manuel Bandeira faz-se presente, por meio de seu famoso "Vou-me embora p'ra Pasárgada / Lá sou amigo do rei / Lá tenho a mulher que quero / na cama que escolherei", muito bem colocado na argumentação do Folião bêbado do século XX, quando em diálogo diacrônico com o Índio do século XVI.?

De Thornton Wilder, nota-se a intertextualidade dramática, mencionada nas instruções da direção para o prólogo da peça brasileira, no qual os professores-autores relacionam a função da personagem Diretora de Cena com aquela do Stage Manager em Our town (Nossa cidade, produzida pela primeira vez em 1938). ${ }^{8}$ Our town é um tributo à vida do indivíduo americano comum e, conseqüentemente, do cidadão universal. Caixa Postal 1500 levanta a bandeira do humanismo defendendo, por meio da antropofagia, da ironia, da carnavalização, da paródia e da sátira, a compreensão e a comunicabilidade entre os povos. Não cabe neste estudo uma análise da estrutura dos dois textos, que apresentam diferenças capitais, mas tanto os três atos da primeira peça, como os inúmeros episódios da segunda desenvolvem-se em torno de uma idéia central, a ser veiculada pelo espetáculo sob a responsabilidade da personagem-diretora. Essa funciona como o fio condutor da montagem, construindo-a a partir de fragmentos narrativos que

\footnotetext{
${ }^{7}$ OLIVEIRA, 2000. p.6.

${ }^{8}$ OLIVEIRA, 2000. p.1.
} 
abrangem figuras históricas, fictícias ou anônimas. Em ambas, as cenas e os episódios são "momentos" pictóricos generalizados do pulsar e da formação do caráter de uma cidade (Our town) e de um país (Caixa Postal 1500), respectivamente. Em ambas, a personagemdiretora funciona como um elo de ligação entre palco e platéia, como o coryphaeus, isto é, o líder do coro grego encarregado de divulgar, para o espectador, o material histórico do qual emana a ação dramática. É quebrando o realismo que tanto Our Town quanto Caixa Postal 1500 conseguem representar aspectos reais do palco da vida.

Pelé, por exemplo, aparece na fala do negro Possuído, como se fora uma visão e uma previsão do futuro, e em contraste dialógico com a favela. A conversa entre os dois pretos fujões é irônica e jocosa. A paródia e a sátira também surgem como elementos eficientes para a obtenção do riso antropofágico e carnavalizante, capaz de desestabilizar a ideologia da seriedade. Essa técnica, aqui retomada pelos autores da peça, revive a idéia de um ajuste de contas entre senhor e escravo, possuidor e possuído (atente-se para o duplo significado deste vocábulo no contexto) poder e jugo, centro e periferia, colonizador e colonizado:

POSSUÍDO (fala enquanto revira os olhos): Um dia, um menino negro como a gente, de pele escura e carapinha como as nossas, nasce em um quilombo cheio de gente (...) Vejo o menino! (...) está correndo, sendo perseguido, mas ninguém consegue pegá-lo (...) Ele parou! Está esperando o inimigo. Ele corre de um lado, corre de outro... Não entendo!

NEGRO: O que está vendo, homem?

POSSUÍDO: A transmissão não tá muito boa. Agora vejo! Um homem vestido de preto. E vinte e dois homens pretos e também brancos, onze de cada lado, numa relva bem aparadinha. Todos vieram da África e empurram uma esfera p'ra lá e p'ra cá. Em volta dos negros o povo gritando e xingando de marafona o homem vestido de preto (...) O negro que foge com a esfera e ninguém consegue pegar vai ser rei. E quando for rei do nosso quilombo tudo quanto é negro vai estar feito! 
NEGRO: Tá, mas vamos azular, negro!

POSSUÍDO (saindo do transe): Vamos. Parece que a arma, a esfera do negro murchou. Ele se deu bem. Tá morando numa maloca grande, bonita, perto de outras malocas grandes de branco.

NEGRO: E o resto do quilombo?

POSSUÍDO: Estão todos livres. Só que estão tudo socado tudo apinhadinho no morro, em cada cafua que onde tem dois cabe um.

NEGRO: E por que moram lá? Não são livres?

POSSUíDO: Acho que é questão de gosto.

NEGRO: Dos negros?

POSSUÍDO: Dos brancos. Vam'bora, homem, que eu confio é nas minhas pernas! ${ }^{9}$

Nesse diálogo dos escravos, a obsessão pela liberdade e a ironia do texto mesclam a fuga de Negro e Possuído com a corrida dos jogadores no gramado de futebol. O mito Pelé, do menino pobre que se torna poderoso e rico, se lhes apresenta, de imediato, como símbolo de esperança, mas se desfaz ao passo que a arma-esfera murcha, indiciando a incompetência do ídolo para resolver os problemas sociais e promover o "sonho" brasileiro.

Passados 78 anos da realização da Semana de Arte Moderna de 1922, que marcou a inauguração do Modernismo no Brasil, Caixa Postal 1500 recoloca na ordem do dia o texto provocador do "Manifesto" de Oswald de Andrade, que vai buscar, na prática antropofágica da sociedade indígena, a fonte que alimentará seu apetite pela independência sócio-intelectual do povo brasileiro. Para justificar a adoção desse rito de sacrifícios, visando a uma transformação na atitude estético-cultural do país, ele explica:

Porque nós somos, antes de tudo antropófagos... Sim, porque nós da América - nós o autóctone: o aborígene - rodeamos o cerimonial

${ }^{9}$ OLIVEIRA, 2000. p.15-16. 
antropófago de ritos religiosos. Comer um ser igual para o índio não significa odiá-lo. Ao contrário: o bugre sempre comeu aquele que lhe parecia superior. ${ }^{10}$

Esse escritor revolucionário redimensiona, pelo choque, a questão da identidade brasileira, foco da peça, com o jocoso, original e conhecido trocadilho-blague, "Tupi or not Tupi, that is the question", paródia da famosa fala de Hamlet, em seu solilóquio de caráter existencial. A alusão refere-se, metaforicamente, ao âmago da proposta antropofágica e deixa clara a intenção de Oswald quanto à mudança do perfil estético brasileiro. O projeto do "Manifesto" caracteriza-se ainda pelo recorte fragmentário da narrativa, pela redução do lirismo, pela ruptura com o discursivo, pela denotação inconformista, e pela operação estranhamento. Caixa Postal 1500 retoma, explicitamente, a postura antropofágica oswaldiana.

A devoração do bispo Sardinha pelos índios, após o naufrágio do navio que o trazia para o Brasil, foi utilizada no "Manifesto antropófago", como metáfora do golpe que rompe os grilhões culturais impostos pela tradição dos colonizadores. A idéia é render uma homenagem "carnavalizada" a todos os opressores que, na pessoa do religioso, deveriam ser simbolicamente comidas. Para legitimar sua convicção brasileira separatista, Oswald de Andrade propõe um novo calendário nacional com início em 1554, ano da morte do bispo. Argumenta, à vista disso, que a história brasileira deve iniciarse nessa data comemorativa da reação autóctone antropofágica contra o poder alienígena. Caso a proposta tivesse sido aceita, estaríamos hoje, no ano 446 da era da deglutiçao de Sardinha. A "antropofagia" foi uma resposta satírica e grotesca a uma atitude do País, que cultivava valores burgueses etnocêntricos, herdados do europeu, e que, não só resistia à abertura de espaços para outros raciocínios, como os desconsiderava. Trata-se pois de uma resistência por parte do colonizado, no sentido de dessacralizar a herança cultural do colonizador, para inaugurar uma nova tradição. Com a

${ }^{10}$ ANDRADE, 1990. p.43-44. 
afirmativa: "O bispo Sardinha como todo o mundo sabe foi deglutido pelos índios. E aqui começa o caos.", ${ }^{11}$ a peça introduz a prática antropofágica, recitada pelos selvagens - na forma como a interpretou e registrou Oswald de Andrade - em diálogo com a instituição religiosa, interpretada e aqui representada pela personagem clerical:

SARDINHA: $\quad$ E o Senhor disse: "Este é o concerto que farei em vós (...)"

RANGAI: (...) Só a Antropofagia nos une.

SARDINHA: Conheces a minha língua... e portanto meu Deus! (...)

RANGAI: $\quad$ Só me interessa o que não é meu. Antropofagia, a absorção do inimigo sacro.

ÍNDIO SELVAGEM: Para transformá-lo em totem.(Cutuca o bispo e lambe os beiços.)

SARDINHA: Tu não impedirás minha fatal jornada! (...)

RANGAI: $\quad$ Antes dos portugueses terem descoberto o Brasil, o Brasil tinha descoberto a felicidade.

ÍNDIO SELVAGEM: Já tínhamos o comunismo.

RANGAI: A língua surrealista. (...)

ÍNDIO SELVAGEM (lambe os beiços): Antropofagia. (...)

RANGAI: (...) Só a Antropofagia nos une (...)

ÍNDIO SELVAGEM (começando a desamarrar o bispo) Tupi or not Tupi that is the question. (...)

ÍNDIO VELHO: Só a Antropofagia nos une. Socialmente. Economicamente. Filosoficamente. ${ }^{12}$

Rangai, Índio Selvagem e Índio Velho são, aqui, os porta-vozes de Oswald de Andrade. O texto como um todo, mas em especial a passagem citada, ecoa a idéia da destruição da linguagem tradicional e dos temas passadistas. Ao recortar e recordar, a peça repete as

11 OLIVEIRA, 2000. p.42.

${ }^{12}$ OLIVEIRA, 2000. p.42-44. 
mesmas fórmulas de rejeição ao discurso do poder do colonizador, que se estendem a postulações religiosas, morais e à organização do Brasil de ontem, retratado na performance de hoje. O riso debochado e sarcástico de Andrade também se repete na resposta do espectador, ecoando, paradoxalmente, a seriedade e profundidade do raciocínio de Walter Benjamim ao registrar que

"Articular historicamente o passado não significa conhecê-lo como ele de fato foi, significa apropriar-se de uma reminiscência, tal como ela relampeja no momento de um perigo. Cabe ao materialismo histórico fixar uma imagem do passado como ela se apresenta no momento do perigo, ao sujeito histórico, sem que ele tenha consciência disso." 13

O amálgama das vozes esclarece que o riso carnavalizante não fala o discurso do poder, mas nele penetra e o desconstroi; dialoga com ele e nele se inscreve. O carnaval traz à tona o dizer velado do "outro" que o poder reprime. Numa segunda instância ele é uma confluência de discursos descontínuos e repentinos. A literatura irônico-carnavalizante abrange em si o dialogismo e a polifonia, e tem como recurso fundamental a paródia. Em seu estudo sobre Dostoievski, Bakhtin caracteriza o concerto polifônico, o mesmo utilizado em Caixa Postal 1500, como uma pluralidade de vozes que se orquestram sem a perda de sua autonomia.

Inscreve-se nessa teoria a Cena Final da Batalha, na qual um Folião do carnaval hodierno irrompe, no passado, com sua bandeira branca, no meio dos índios em guerra, gritando: "Sou amigo! Sou amigo! Não tenho nada a ver com isso. Não sou Vasco da Gama nem Flamengo. Nem gosto de futebol!” Ao que os índios retrucam em coro, como se fizessem parte da torcida do time da seleção brasileira: "Olê, Olê, Olê, Olê, / Brasil, Brasil..."14 Para completar a insensatez (nonsense), surge um grupo de cinco portugueses, em uma caravela, um deles vestido de goleiro e os outros usando camisas da seleção de

13 BENJAMIM, 1994. p.224.

${ }^{14}$ OLIVEIRA, 2000. p.44. 
Portugal, além de chapéus, calças, e adereços do século XVI. Eles trazem elementos de percussão e chegam fazendo muito barulho. e, por sua vez, respondem, "Purtugal, Purtugal, Purtugal, Purtugal" ${ }^{15}$ no meio de vaias e assobios dos nativos. A batalha continua calcada em músicas parodiadas:

PORTUGUESES: Ei, você ai, nós vamos invadir,/Nós vamos invadir (...)

ÍNDIOS: $\quad$ (exibindo uma caveira, vestida com a camisa da seleção francesa e espetada em um espeto gigante de churrasco): Oi, sou antropófago, /Com muito orgulho, /Com muito amor (...)

PORTUGUESES: (depois de vaiar): A Amália Rodrigues canta, /A massa se levanta, /E só dá fado, / $\hat{E}, \hat{E}, \hat{E}, \hat{E}, \hat{E}, \hat{E}, \hat{E}, \hat{E}$, /Bota p'ra fuder (...)

ÍNDIOS: (vaiam e respondem): Sou, sou índio, eu sou, /Vou dar flechada, eu vou, / E ninguém vai me segurar, / Nem jesuíta (...) (os índios disparam uma chuva de flechas sobre os portugueses, que se afastam assustados. Os índios comemoram como se fosse um gol, continuando): "Ah, tô mameluco! /Ah, tô mameluco! /Brasil, Brasil, Brasil (...)" (enquanto os índios comemoram, os portugueses saem de cena por alguns instantes, voltando com um canhão. Eles disparam em cima dos índios um tiro que faz um barulho ensurdecedor, enchendo o palco de fumaça, os índios caem todos mortos e os portugueses levantam bandeiras de Portugal e comemoram).

PORTUGUESES: (comemorando e saindo, eles vão chutando os cadáveres dos índios para fora da cena): Rei, Rei, Rei, / D. João é o nosso Rei / É Purtugal, / É Purtugal / É Purtugal. ${ }^{16}$

A Batalha Final de extermínio encena um grande carnaval povoado de máscaras representantes dos aborígenes (os autóctones); do

15 OLIVEIRA, 2000. p. 45.

${ }^{16}$ OLIVEIRA, 2000. p.45-46. 
brasileiro contemporâneo alienado (o Folião, que em sua fala intertextualiza o time de futebol com o navegador português Vasco da Gama e com os holandeses); dos portugueses ("descobridores" e colonizadores da terra brasilis); dos franceses (os invasores, cuja presença, na peça, se mistura com a vitória do jogo decisivo de futebol, quando da disputa pela Copa, no campeonato mundial de 1998, realizado na França). O espetáculo mescla referências históricas claras com lendas imprecisas - tais como a da criação do mundo, de acordo com a crença do povo guarani. Nele as várias máscaras e vozes coabitam para construir uma espécie de paródia dos sistemas que se entrecruzam; um macrossigno complexo, de elementos múltiplos e distintos, cuja articulação imprevista carrega uma força crítica inusitada. Caixa Postal 1500 funciona como voz denunciadora e se nutre de um sentimento trágico interno, de uma tensão paradoxal em que a bipolaridade (dominante/dominado) se encontra, todo o tempo, questionada.

Dando asas à imaginação, o cenógrafo Francisco Magalhães transforma o Espaço Cine Horto num ambiente que mescla uma floresta de bambus com uma clareira semelhante a uma arena de touros. Da mesma forma, Ana Lana Gastelois (figurinista), a equipe de iluminação (Alexandre Galvão, Wladimir Medeiros e Francisco Pelúcio), os preparadores Babaya (voz) e Dudude Herrmann (corpo) realizam uma notável criação teatral por onde a trama navega, transportando o clima correto para as cenas propostas pelos autores, conduzida pelo diretor e realizada pelos atores. Consegue-se tirar, do cenário simples, um efeito original, eficiente e inovador.

O elenco identifica-se com os diversos planos narrativos pelos quais transita, registrando maiores destaques individuais nas performances de Carlos Batista (Gusmão), Helvécio Izabel (Elesbão), Ana Regis (Mariano), Nyvea Karam (Anarê), Ramom Braga (Navarro) e Sávio William (Benedito). O desempenho dos atores, imbuídos da caracterização de seus personagens, confere-lhes o aplauso do público. Eles demonstram domínio da arte mimética, segurança quanto ao universo histórico-performático escolhido, e capacidade de torná-lo agradável à platéia como cultura e divertissement. 
Atraente, divertida, séria, analítica, engajada, instrutiva e de bom gosto, Caixa Postal 1500 oferece, com ironia, bom humor, nonsense e alguns efeitos melodramáticos que comovem a audiência, não somente, uma trama bem estruturada, como ainda uma reflexão sobre o País. É bem verdade, e mesmo curioso, que, dentro da fórmula do modernismo contemporâneo (pós-modernismo?) utilizada nessa peça, perceba-se também nela aquele mesmo comprometimento paradoxal com a tradição e o uso de clichês que enfatizam a inexorabilidade e o determinismo históricos.

\section{Referências Bibliográficas}

ANDRADE, Oswald de. Os dentes do dragão: entrevistas. São Paulo: Globo/SEC, 1990. (Obras completas).

ANDRADE, Oswald de. Manifesto antropófago. In: Vanguarda européia e modernismo brasileiro. Ed. Gilberto Mendonça Teles. 11.ed. Petrópolis, RJ: Vozes, 1992.

ANUNCIAÇÃO, Miguel. Campanha de popularização tem 71 peças. Hoje em dia: teatro-cinema/perspectivas 2000, Belo Horizonte, p.3, 1 jan., 2000.

ANUNCIAÇÃO, Miguel. Peça ‘Caixa Postal 1500’ volta hoje ao cartaz em BH. Hoje em dia: cultura, Belo Horizonte, p.3, 9 mar., 2000.

ASSIS, Júlio. 'CXPostal 1500' conta história do Brasil. O Tempo: magazine-Minas, Belo Horizonte, p.3, 27 jan., 2000.

BAKHTINE, Mikhail. La poétique de Dostoievski. Paris: Seuil, 1970. BENJAMIN, Walter. Magia e técnica, arte e política: ensaios sobre a literatura e história da cultura. Trad. Sérgio Paulo Rouanet, 7.ed., São Paulo: Brasiliense, 1994.

CASSESE, Patrícia. Galpão encena saga do descobrimento. Hoje em dia: cultura, Belo Horizonte, p.3, 27 jan. 2000.

GREENBLATT, Stephen. Marvelous possessions: the wonder of the New World. Chicago: The University of Chicago Press, 1991. 
GUIMARÃES, Pedro. História sob novo prisma. Estado de Minas: espetáculos/artes cênicas, Belo Horizonte, p.6, 27 jan., 2000.

OLIVEIRA, Georgia et alli. Caixa postal 1500. Manuscrito inédito, 2000.

PIRES, Pablo. Galpão usa Descobrimento como tema de seu Oficinão.

O tempo: magazine-crônica, Belo Horizonte, p.8, 8 jan., 2000.

SELDEN, Raman. A reader's guide to contemporary literary theory. 3.ed. Lexington: The University Press of Kentucky, 1993.

TELES, Gilberto Mendonça, ed.. Vanguarda européia e modernismo brasileiro. 11.ed., Petrópolis, RJ.: Vozes, 1992.

WILDER, Thornton. Our town. New York: Harper \& Row, 1985.

\section{Resumo}

Leitura da peça Caixa Postal 1500, que retrata um olhar coletivo sobre o caráter, a formação e a colonização do Brasil. O texto é assinado por uma equipe composta de professores da UFMG (Universidade Federal de Minas Gerais) e produzido pela Oficina de Atores e de Dramaturgia do Grupo Galpão - 1999. A montagem é um encontro de história, música, teatro e literatura, no qual o "Manifesto antropófago" de Oswald de Andrade recebe lugar de destaque.

\section{Abstract}

This essay is a reading of the play Caixa Postal 1500, which portrays a collective look over the Brazilian character, its formation and the colonization of the country. The text is signed by 10 UFMG (Universidade Federal de Minas Gerais, Belo Horizonte, Brazil) professors and produced by a Brazilian (mineiro) theatre group, named Oficina de Atores e de Dramaturgia do Grupo Galpão - 1999. The staging is a meeting of history, music, theatre and literature, in which Oswald de Andrade's "Manifesto antropófago" ("Antropophagic manifest", a reaction against European colonization) is duely emphasized. 